\title{
MODELING OF SUBSURFACE HORIZONTAL POROUS PIPE IRRIGATION UNDER DIFFERENT CONDITIONS
}

\author{
Z.K. Rasheed \\ Assist Lecturer \\ Dept. of Water Res. Engin.-Coll. of Engin.-University of Baghdad \\ kamel_zena@yahoo.com
}

\section{ABSTRACT}

Horizontal porous pipe method is one of the most efficient systems of irrigation in arid and semi-arid areas. The main aim of this study is to simulate the subsurface horizontal porous pipe irrigation under different conditions. By this method of irrigation, an optimum amount of water is reached to the crop. Moreover, it saves more water than the other irrigation systems. Simulation models by HYDRUS/2D are described the distribution of wetting shapes in two different soil textures through the system of United States Department of Agriculture, USDA, namely as loam and silt soils. The system is designed for three diameters of 6,7 , and 8 cm installed at 15, 20, and $25 \mathrm{~cm}$ below the soil surface under three application heads of 25 , 50 , and $75 \mathrm{~cm}$. Horizontal and vertical advance of the wetting front shapes in loam are greater than silt soil. The numerical values of horizontal and vertical advance are compared with those of predicted by the formulas, showing that average relative error values not more than $2 \%$. This indicated that the formulas may be used as a tool for designing and investigating the subsurface horizontal porous pipe irrigation system.

Keywords: Wetting shapes, HYDRUS/2D, horizontal porous pipe system, simulation model, subsurface irrigation.

رشيد

959-949:4) 52: 2021- مجلة العلوم الزراعية العراقية

$$
\begin{aligned}
& \text { نمذجة انبوب ري مسامي افقي تحت شروط مختلفة } \\
& \text { زينة كامل رشيد } \\
& \text { مدرس مساعد } \\
& \text { قسم هندة الموارد المائية- كلية الهندسة- جامعة بفداد }
\end{aligned}
$$

المستخلص

يعتبر الري بالانابيب المسامية الافقية واحدا من اكثر الطرق كفاءة في المناطق القاحلة وشبه القاحلة. الهذف الرئيسي من هذه الدراسة هو نمذجة انبوب ري مسامي افقي تحت شروط مختلفة. ان باستخدام طريقة الري هذهر يتم وصول الكمية المثلى من الماء الى النبات. وعلاوة على ذلك, فانه يوفر المزيد من المياه مقارنة بانظمة الري الاخرى. النماذج المستخدمة في برامج هايدرس ذات البعد الثنائي قد وصفت توزيع اشكال الترطيب في قوامين مختلفين من الترب وذلك من خلال نظام وزارة الزراعة بالولايات المتحدة, وزارة الزراعة الامريكية, وهذه الترب هي التربة الطميية والتربة الغرينية. تم تصميم هذا النظام بثلاثة اقطار وهي 6 و 7 و 8 سم موضوعة باعماق 15 و 20 و 25 سم تحت سطح التربة تحت ثلاث ضغوط مسلطة 25 و50 و و 75 سم. ان التقدم العمودي والافقي لجبهات الترطيب كان اكبر في الترب الطميية مقارنة بالترب الغرينية. وقد تم مقارنة القيم العمودية والافقية لجبهات الترطيب مع تلك المتوقعة من الصيغ, والتي تبين ان متوسط قيم الخطأ النسبي لا يزيل عن 2 \% . يشير هذا الى امكانية استخدام هذه الصيغ كأداة لتصميم وفحص نظام الري بالانابيب المسامية تحت السطحية. الكلمات المفتاحية: جبهات الترطيب ,هايدرس ثناثي البعد، نظام الانابيب المسامية الافقية ،نماذج المحاكاة, الري تحت 


\section{INTRODUCTION}

Irrigation system with subsurface horizontal porous pipe is a suitable method by reducing deep percolation and evaporation through applying a low level of water. To assess irrigation system, researchers have studied several methods including drippers, pots, and porous pipes. Ashrafi, et al. (3) simulated the infiltration from a subsurface clay pipe irrigation by using a computer program and validated with a laboratory experiment. They found that the shape of the wetted zone is sensitive to the applied water and the depth of the installation. Qiaosheng, et al. (14) used a subsurface porous pipe irrigation and developed an analytical model for the soil wetting pattern. A high accuracy was found through statistical comparison between observed and predicted soil wetted dimensions. Akhoond and Golabi (1) tested a vertical installation instead of horizontal of the porous pipe as a new idea of irrigation. The system of subsurface irrigation is designed for three lengths of the porous pipe of 30,45 , and $60 \mathrm{~cm}$ with 2, 4, and $6 \mathrm{~m}$ as applied heads. The results showed a vertical expansion to the about $200 \%$ of the soil moisture content and an acceptable horizontal expansion only for 6 $\mathrm{m}$ applied head. Kandelous and Simunek (8) evaluated the distribution of water contents around subsurface emitter by using the HYDRUS in clay loam soil and compared the results with laboratory experiments. Based on The statistical parameters they found that the corresponding between simulation and observation were very good. Siyal and Skaggs (18) investigated the simulation of soil wetting patterns with HYDRUS for subsurface porous clay pipe irrigation. The simulations showed a larger expansion in horizontal direction in fine soils. Siyal, et al. (19) assessed the viability of the porous pipes irrigation as a technique of water conservation. They conducted an experimental study on an area of sandy loam with segments of $40 \mathrm{~cm}$ length of clay pipe buried at a depth of $0.43 \mathrm{~m}$. The experimental results showed that with clay pipe irrigation method, water saving up to $80 \%$ when compared with surface irrigation method. Igbdun and Barnabas (7) presented the hydraulic characteristics for three types of porous clay pipes made of pure clay, clay- sand mixture, and clay- sand- sawdust mixture. The clay pipes were buried at a depth of $25 \mathrm{~cm}$ under the soil surface. They found that the rate of seepage and the hydraulic conductivity of the porous pipe are influenced by the materials which use for making the porous pipe. Khan, et al. (9) studied the effect of porous pipe characteristics by carrying out laboratory experiments under a system of subsurface irrigation which is negative pressure difference. This system is effective in management of irrigation water and can be used as alternative to other traditional methods with efficiency ranges from 0.94 to 0.97 . Rasheed (16) used buried ceramic pipes installed vertically in different soils textures of USDA classification to develop empirical formulas. The empirical formulas were function of pipe length, applied head, initial soil water content, and pipe hydraulic conductivity through different operation times. Available measured data were used to compare with those predicting from formulas which were in a good accuracy. Al-Mhmdy and AlDulaimy (2) conducted a field experiment to evaluate the performance for drip irrigation system. The experiment was included with two factors, the emitter discharge with two levels and the operational pressure with three levels. A decrease values was showed in emission uniformity and uniformity coefficient. While the results showed with the increase of operational pressure, variation ratios and the rates of discharge have been increased. Khattb and El-Housini (10) evaluated some lentil varieties with using two types of irrigation systems of dripping and sprinkler in sandy soil. The two field experiments were carried out which showed a highest values for studied characters in drip irrigation than sprinkler irrigation. Rahi and Faisal (15) used a treatment system of horizontal subsurface flow in the constructed wetland. The system was filled with gravel and planted for treatment purposes. The results showed a good efficiency for the treatment which was 84.2, 55.4 and $72.7 \%$. Rasheed (17) simulated the wetted area on subsurface drip irrigation by using HYDRUS/2D with two soil textures of sandy loam and loamy sand. The system of subsurface drip irrigation was designed 
through three diameters of dripper which was $1,1.5$, and $2 \mathrm{~cm}$ under different conditions. The results of distribution of the soil water contents are gathered to obtain formulas. The formulas were good with average relative error less than $3 \%$. The aims of this research are to improve management of irrigation system with using of subsurface horizontal porous pipe, by studying the distribution of water contents in both axes and studying the involved parameters of the empirical approaches such as the hydraulic heads, pipe diameters, and the installation depths through the running times.

\section{MATERIALS AND METHODS}

Numerical model have been developed for simulating subsurface porous pipe irrigation.

\section{Water Flow Equation}

The equations govern the water flow can be listed below. First writing the general form of Darcy's law which can be states as [Hillel (6)]: $\mathrm{q}=-\mathrm{K}(\theta) \nabla \mathrm{H}$

In three dimensional flow, the continuity equation will be:=

$\frac{\partial \theta}{\partial \mathrm{t}}=-\nabla \cdot q$

Water flow in a general form can be written as [Kirkham and Powers (11)]:= $\frac{\partial \theta}{\partial \mathrm{t}}=\nabla \cdot[\mathrm{K}(\theta) \nabla \mathrm{H}]$

The above equation must be solved for $\mathrm{H}$, which is the sum of pressure head and gravitational head. The general form can identify as of Richards' equation:=

$\frac{\partial \theta}{\partial \mathrm{t}}=\nabla \cdot[\mathrm{K}(\mathrm{h}) \nabla \mathrm{h}+\mathrm{K}(\mathrm{h})]$

The flow in a two dimensional porous media will be:

$\frac{\partial \theta}{\partial \mathrm{t}}=\frac{\partial}{\partial \mathrm{x}}\left[\mathrm{K}(\mathrm{h}) \frac{\partial \mathrm{h}}{\partial \mathrm{x}}\right]+\frac{\partial}{\partial \mathrm{Z}}\left[\mathrm{K}(\mathrm{h}) \frac{\partial \mathrm{h}}{\partial \mathrm{Z}}\right]+\frac{\partial \mathrm{K}(\mathrm{h})}{\partial \mathrm{Z}}$

Where: $=======\theta \quad$ volumetric soil water content, $L^{3} / L^{3}$,

$\mathrm{t}=$ time, $T$

$q \quad=$ the flux density of water, $L / T$

$\mathrm{h} \quad=$ pressure head, $L$

$\mathrm{K}(\theta)=$ the unsaturated soil water conductivity, $L / T$, and

$\mathrm{K}(\mathrm{h})=$ the unsaturated hydraulic conductivity of the soil as a function of pressure head, $L / T$.

Numerical and analytical solutions to solve the differential equation became feasible. For estimating the hydraulic properties in HYDRUS/2D several analytical models are used: [Brooks and Corey (4); van Genuchten
(20); Vogel and Cislerova (21); Kosugi (12); and Durner (5)].

The Van Genuchten relationships are used for modeling the soil hydraulic properties as follows:=

$\theta(h)=\left\{\begin{array}{c}\theta_{\mathrm{r}}+\frac{\theta_{\mathrm{s}}-\theta_{\mathrm{r}}}{\left(1+|\alpha \mathrm{h}|^{\mathrm{n}}\right)^{\mathrm{m}}} \mathrm{h}<0 \\ \theta_{\mathrm{s}} \quad \mathrm{h} \geq 0\end{array}\right.$

$\mathrm{K}(\mathrm{h})=\mathrm{K}_{\mathrm{s}} \mathrm{S}_{\mathrm{e}}^{\mathrm{l}}\left[1-\left(1-\mathrm{S}_{\mathrm{e}}^{1 / \mathrm{m}}\right)^{\mathrm{m}}\right]^{2}$

$\mathrm{S}_{\mathrm{e}}=\frac{\theta-\theta_{\mathrm{r}}}{\theta_{\mathrm{s}}-\theta_{\mathrm{r}}}$

$\mathrm{m}=1-1 / \mathrm{n}$

Where:

$\theta(\mathrm{h})=$ water content as a function of pressure head, $L^{3} / L^{3}$,

$\theta_{r} \quad=$ residual soil water content, $L^{3} / L^{3}$,

$\theta_{s}=$ saturated soil water content, $L^{3} / L^{3}$,

$\alpha \quad=$ the air entry inverse, $L^{-1},=K_{s}=$ saturated hydraulic conductivity of the soil, $L / T$,

$S_{e}=$ the effective saturation, $\frac{L^{3}}{-} L^{3}$,

$l=$ the pore conductivity parameter, dimensionless, and

$n=$ the pore size distribution index, dimensionless.

Numerical models in HYDRUS/2D can use to solve the flow problem. Suitable conditions are required to solve equation (5); these are known as the Initial and boundary condition. The HYDRUS simulation of horizontal porous pipe is occurring by using a rectangular model with a horizontal dimension of $60 \mathrm{~cm}$ and a vertical dimension of $80 \mathrm{~cm}$ with a semicircle shape that representing the horizontal pipe. Initial soil water contents are used as initial conditions which are specified inside the model. The boundary condition at the horizontal pipe is a variable head boundary condition, while a free drainage boundary condition is used at the bottom of the model. Fig. 1 shows a section of the model that considered for simulation. The model is described as two parts of cells; the first part is indicted to the cells along the soil surrounding the horizontal pipe, thereby the second part of cells is the horizontal porous pipe. 




Fig. 1. Section of model

\section{Main assumptions}

The most direct assumptions for solving the problem of flow can be specified as; the evaporation across the soil surface can be significantly negligible, so it is set to be zero. During this period of work, soil is homogeneous and isotropic. Moreover, the distribution of water contents around a subsurface pipe is regular.

\section{Initial and boundary conditions}

Due to symmetrical about the vertical line of subsurface pipe, half of soil profile is simulated. The model consists of two dimensions using the soil water content as initial condition. A variable head boundary condition is used along the horizontal pipe. Along the boundary that representing the bottom of the model a free drainage boundary condition is used, while all other parts are specified as no flux.

\section{Numerical simulations}

HYDRUS/2D is used to simulate water flow around the horizontal pipe by using (USDA) system of soil classification. Table 1 show the hydraulic parameters of the two soil textures used in the simulation.

Table 1. Hydraulic parameters of the two soil textures

\begin{tabular}{|c|c|c|c|c|c|}
\hline $\begin{array}{l}\text { Soil } \\
\text { texture }\end{array}$ & $\begin{array}{l}\boldsymbol{K} \boldsymbol{s} \\
\mathrm{cm} / \\
\boldsymbol{h r}\end{array}$ & $\begin{array}{c}\boldsymbol{\theta}_{r} \\
\mathrm{~cm}^{3} / \mathrm{cm}^{3}\end{array}$ & $\begin{array}{c}\theta_{s} \\
\mathrm{~cm}^{3} / \mathrm{cm}^{3}\end{array}$ & $\begin{array}{r}\alpha \\
c m^{-1}\end{array}$ & $n$ \\
\hline Loam & 1.04 & 0.078 & 0.430 & 0.036 & 1.56 \\
\hline Silt & 0.25 & 0.034 & 0.460 & 0.016 & 1.37 \\
\hline
\end{tabular}

According to the recommended values for mean soil water contents at wilting point for the two soils in the USDA soil texture classification [Meyer et al.,(13)], the initial soil water contents for loam and silt soil respectively are $0.094 \mathrm{~cm}^{3} / \mathrm{cm}^{3}$ and 0.089 $\mathrm{cm}^{3} / \mathrm{cm}^{3}$, so for the initial condition that used in the model is $0.1 \mathrm{~cm}^{3} / \mathrm{cm}^{3}$ for the two soils. Variable head boundary conditions are used of 25,50 , and $75 \mathrm{~cm}$. The porous pipe is buried at depths of 15,20 , and $25 \mathrm{~cm}$. Additionally, the system is designed for three pipe diameters of 6,7 , and $8 \mathrm{~cm}$ as outer diameter with wall thickness of $1 \mathrm{~cm}$. The predicted distribution of water contents are recorded for $0.5,1,1.5$, $2,2.5$, and 3 hours as the running time. As can be seen later the wetted width and depth to which the wetting patterns are moved during the irrigation event.

\section{RESULTS AND DISCUSSION \\ Influence of different parameters}

The distribution of water contents around the subsurface porous pipe is affected by several parameters. These parameters include soil texture (loam or silt), running time, applied heads, depths of installation, moreover the diameter of porous pipe.

\section{Effect of soil texture}

To see the effect of soil texture simulation shown in Figure 2 is extended to three hours as the running time using two soil textures of loam and silt. The simulation shows that water contents distribution in loam soil is increasing more than silt soil as time progresses although use the same saturated hydraulic conductivity of the porous pipe. During the same conditions of maximum pipe diameter of $8 \mathrm{~cm}$, maximum applied head of $75 \mathrm{~cm}$, installation depth of $25 \mathrm{~cm}$, and with $0.1 \mathrm{~cm}^{3} / \mathrm{cm}^{3}$ as the initial soil water content for both soils, the soil profile water content is deeper in loam soil than silt with more than 10 $\%$. Similarly, is wider more than $20 \%$ also in the loam than silt soil.

Effect of installation depths or buried depths

It is important to realize the effect of buried depths as to be shallow or deep, so the water content must not be closer to the soil surface. Water content profile would have large expansion in vertical direction as compared with horizontal. Figure 3 shows the effect of 
15,20 , and $25 \mathrm{~cm}$ as installation depth of the porous pipe.

\section{Effect of running time}

In discussing running time, Figure 4 refers to the water content distribution with increment of time. It is apparent increase water contents through the profile for a loamy soil textural after 1, 2, and 3 hours, installation depth of 15 $\mathrm{cm}$, and with pipe diameter of $7 \mathrm{~cm}$.

Effect of pipe diameter



The same conditions used in water contents profiles as shown in Figure 5, but these profiles consist of 6,7 , and $8 \mathrm{~cm}$ pipes diameters. The distribution of water contents has approximately the same percentage of increment for the $\mathrm{x}$ - and $\mathrm{z}$ - axes.

\section{Effect of applied heads}

The percentage of increment of the $\mathrm{x}$-axis is approximately twice the y-axis as the applied head changes from $25 \mathrm{~cm}$ to $75 \mathrm{~cm}$ as seen later in Figure 6.

Fig. 2. Modeling of porous pipe irrigation in a) loam and b) silt soils with $8 \mathrm{~cm}$ porous pipe

outer diameter, installation depth of $25 \mathrm{~cm}$, and after $3 \mathrm{hr}$ running time 




Fig. 3. Modeling of porous pipe irrigation in loam soil with $6 \mathrm{~cm}$ pipe diameter, running time of $3 \mathrm{hr}$, and with 15, 20, and $25 \mathrm{~cm}$ as installation depths 


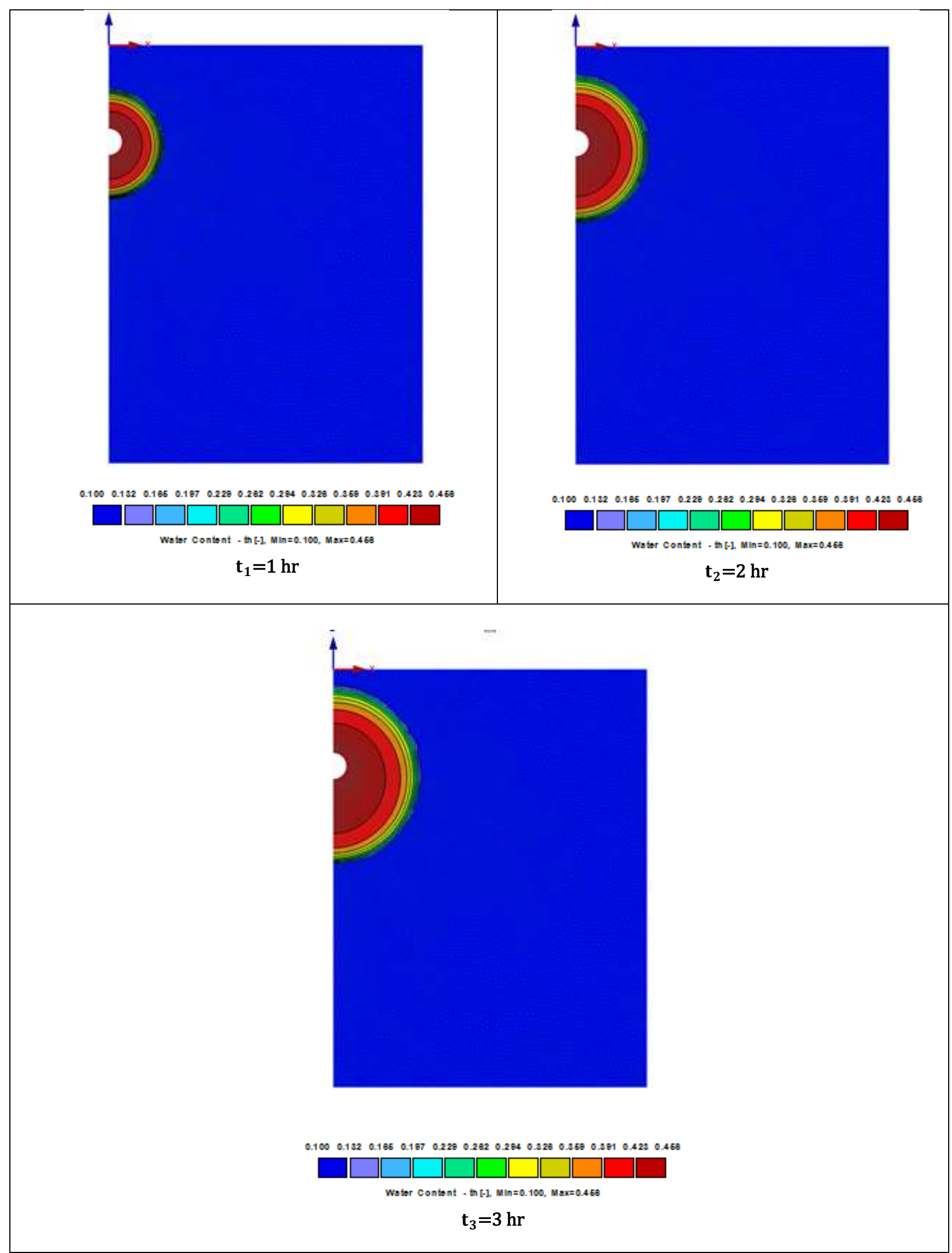

Fig. 4. Modeling of porous pipe irrigation in loam soil with $7 \mathrm{~cm}$ pipe diameter, installation depth of $15 \mathrm{~cm}$, and after 1,2 , and 3 hours 


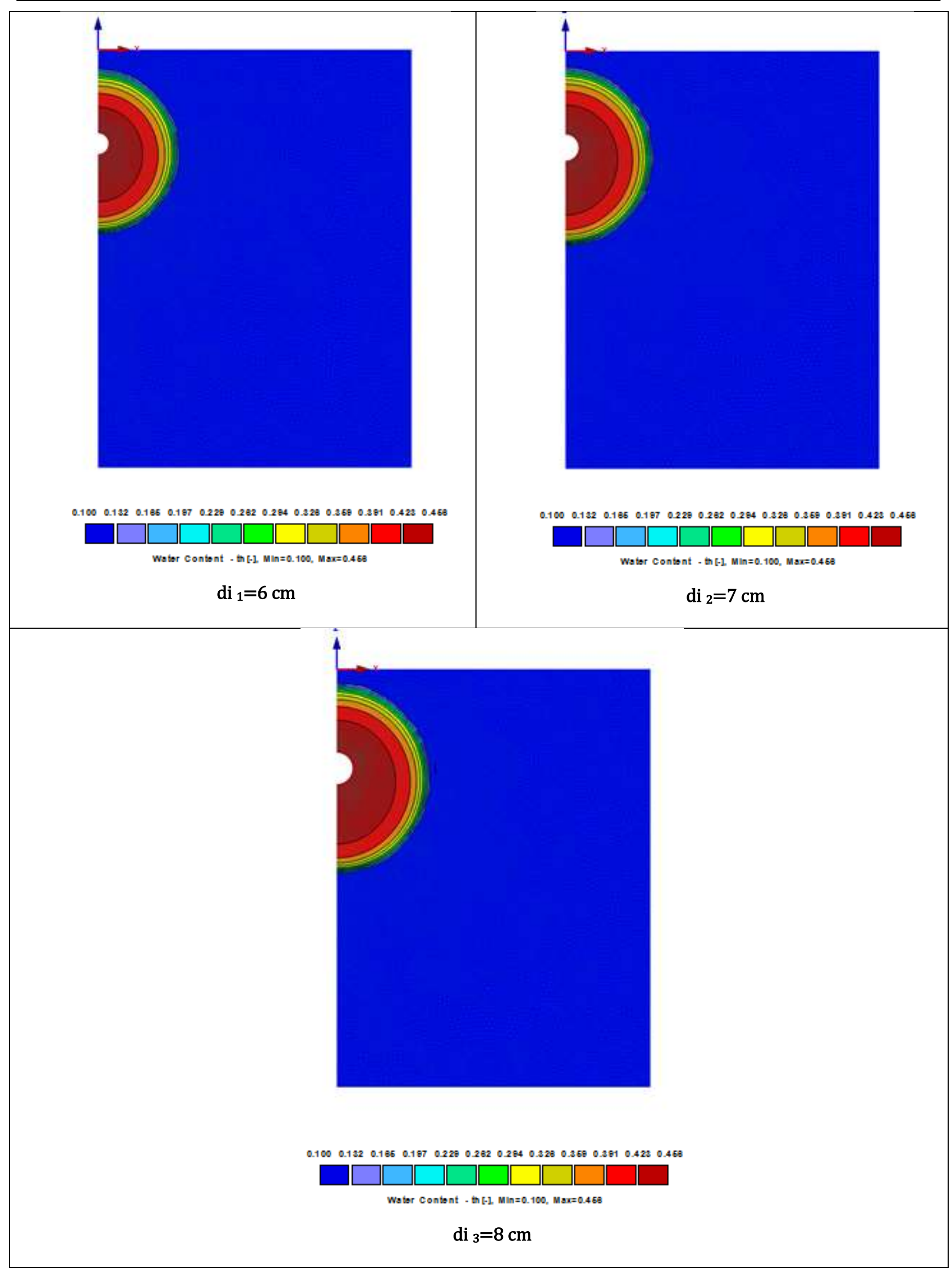

Fig. 5. Modeling of porous pipe irrigation in loam soil with $15 \mathrm{~cm}$ installation depth, $3 \mathrm{hr}$ running time and with 6,7 , and $8 \mathrm{~cm}$ as pipes diameters. 


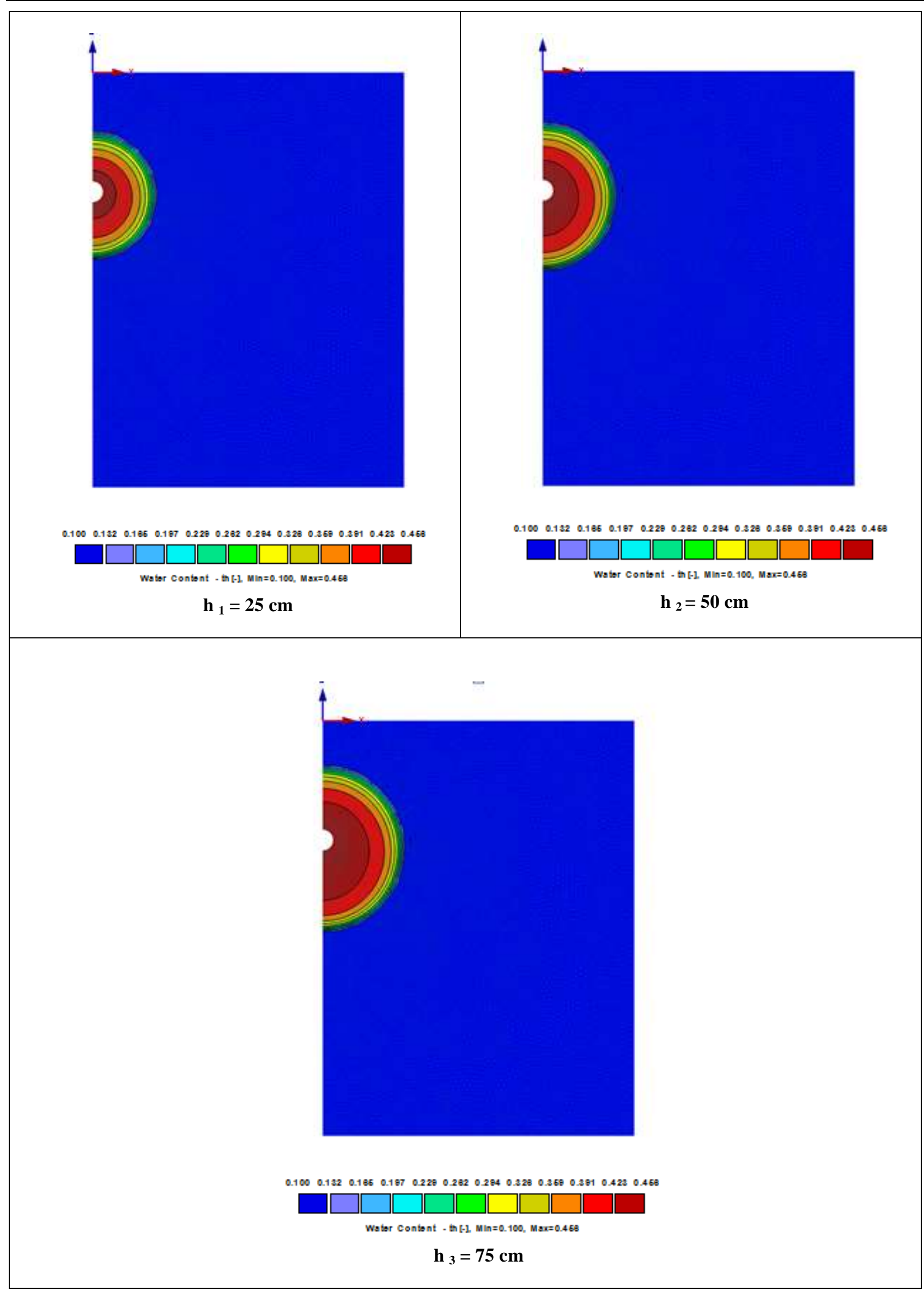

Fig. 6. Modeling of porous pipe irrigation in loam soil with $20 \mathrm{~cm}$ installation depth, $3 \mathrm{hr}$ running time, $6 \mathrm{~cm}$ pipe diameter, and with 25,50 , and $75 \mathrm{~cm}$ as applied heads 


\section{Empirical approach}

The formula can be used to predict the distribution of water content. To do this, approaches in table 2 and table 3 are indicated for both the silt and loam soil textures and how to find the width on the $\mathrm{x}$-axis and depth on the y-axis. So the formulas are usually a method of expressing soil water contents in centimetre units. Each formula includes the depth of installation, diameter of porous pipe, and applied head at a period of time an. The approaches are obtained by gathered the data in STATISTICA software.

Table 2. Empirical approaches to find the width in both soil textures.

\begin{tabular}{|cc|}
\hline Soil texture & Wetted Width, $X, \mathrm{~cm}$ \\
\hline loam & $1.295 \mathrm{t}^{0.389} \mathrm{di}^{0.496} \mathrm{de}^{0.083} \mathrm{~h}^{0.212}$ \\
silt & $1.277 \mathrm{t}^{0.342} \mathrm{di}^{0.485} \mathrm{de}^{0.078} \mathrm{~h}^{0.194}$ \\
\hline
\end{tabular}

Table 3. Empirical approaches to find the depth in both soil textures

\begin{tabular}{|cc|}
\hline Soil texture & Wetted Depth, $\mathrm{Z}, \mathrm{cm}$ \\
\hline loam & $2.544 \mathrm{t}^{0.142} \mathrm{di}^{\mathbf{0 . 2 8 1}} \mathrm{de}^{0.579} \mathrm{~h}^{0.084}$ \\
silt & $2.565 \mathrm{t}^{0.106} \mathrm{di}^{0.262} \mathrm{de}^{0.606} \mathrm{~h}^{0.058}$ \\
\hline
\end{tabular}

Three statistical measures are used to indicate the approaches performance. These measures are coefficient of determination $\left(\mathrm{R}^{2}\right)$, maximum relative error (Max. RE), and mean or average relative error (Av. RE) based on comparison of data from water contents profiles of HYDRUS/2D and data where determining from approaches. These statistical measures are described as [(Willmott (22)]. Table 4 shows the statistical measures for the width in both soil textures while Table 5 shows the measures for the depth.

Table 4. Statistical measures for the width

\begin{tabular}{|cccc|}
\hline Soil texture & R2 & Max. RE \% & Av. RE \% \\
\hline loam & $\mathbf{0 . 9 9 5}$ & $\mathbf{8 . 0 8 9}$ & 1.482 \\
silt & $\mathbf{0 . 9 9 4}$ & 7.824 & 1.424 \\
\hline
\end{tabular}

Table 5. Statistical measures for the depth

\begin{tabular}{|cccc|}
\hline Soil texture & R2 & Max. RE \% & Av. RE \% \\
\hline loam & $\mathbf{0 . 9 8 5}$ & $\mathbf{7 . 3 2 9}$ & $\mathbf{1 . 4 8 8}$ \\
silt & $\mathbf{0 . 9 9 1}$ & $\mathbf{6 . 8 4 8}$ & $\mathbf{1 . 0 8 7}$ \\
\hline
\end{tabular}

Acceptable performances of approaches are recorded in both Table 4 and Table 5. As a result the accuracy of the approaches which extracted from the data to predict the wetted width and the wetted depth should be well with coefficient of determination, $\mathrm{R}^{2}$ not less than 0.990. The maximum relative error ranges between $6.848 \%$ and $8.089 \%$. Moreover, the average relative error is not more than $2 \%$. So, in a general greater spreading occurs in loam soil than silt soil. The water content in soil profile is deeper in loam soil than silt with more than $10 \%$ and is wider more than $20 \%$. Thus the numerical studies are carried for improving management of irrigation system by studying the distribution of water contents in both axes and studying the involved parameters of the hydraulic heads, pipe diameters, and the installation depths through the running times. Therefore, the empirical approaches are functions of these parameters to design appropriate system using porous pipe.

\section{REFERENCES}

1. Akhoond-Ali, A.M., and M. Golabi. 2008. Subsurface porous pipe irrigation with vertical option as a suitable irrigation method for light soil, Asain J. of Scientific Research, 1(3): 180192

2.Al-Mhmdy, SH.M. and S.E.H. Al-Dulaimy. 2018. Performance evaluation of drip irrigation system according to the suggested standards. Iraqi Journal of Agriculture Sciences, 49(6): 1099-1109

3. Ashrafi, S., A.D. Gupta, M.S. Babel, N. Izumi and R. Loof. 2002. Simulation of infiltration from porous clay pipe in subsurface irrigation. Hydrological Sciences Journal, 47(2): 253-268

4. Brooks, R.H. and A.T. Corey. 1964. Hydraulic properties of pouros media . Hydrol. Paper, 3, Colorado State Univ., Fort Collins, CO, USA

5. Durner, W. 1994. Hydraulic conductivity estimation for soils with hterogeneous pore structure. Water Resour. Res., 30(2): 211-223

6. Hillel, D. 1980. Fundamentals of soil physics. Academic Press, New York

7. Igbdun, H. E. and J. Barnabas. 2013. Hydraulic characteristics of porous clay pipes for subsurface irrigation. The Pacific Journal of Science and Technology, 14(1): 40-47

8. Kandelous, M. M. and J. Simunek. 2010. Numerical simulations of water movement in subsurface drip irrigation system under field and laboratory conditions using HYDRUS-2D. 
Agricalture Water Mangement, 97(7): 10701076

9. Khan, N.N., M.M. Islam, S. Islam, and S.M. Moniruzzaman. 2015. Effect of porous pipe characteristics of soil wetting pattern in a negative pressure difference irrigation system. American Journal of Engineering Research, 4(2): 01-12

10. Khattb, E.A. and E.A. El-Housini. 2019. Evaluation of some lentil varieties under sprinkler and dripping irrigation systems in newly reclaimed sandy soil. Iraqi Journal of Agriculture Sciences, 50(3):753-758

11. Kirkham, D. and W.L. Powers. 1972. Advanced Soil Physics. Wiley - Interscince, New York, pp.534

12. Kosugi, K. 1996. Lognormal distribution model for unsaturated soil hydraulic properties. Water Resour. Res., 32(9): 26972703

13. Meyer, P.D., M.L. Rockhold, and G.W. Gee. 1997. Uncertainty Analyses of Infiltration and Subsurface Flow and Transport for SDMP Sites. NUREG/CR-6565, PNNL11705

14. Qiaosheng, S., L. Zuoxin, W. Zhenying and L. Haijun. 2007. Simulation of the soil wetting shape under porous pipe sub-irrigation using dimensional analysis. Irrig. Drain. 56(4): 389-398

15. Rahi, M.A. and A.A.H Faisal. 2019. Using horizontal subsurface flow constructed wetland system in the treatment of municipal wastewater for agriculture purpuses. Iraqi Journal of Agriculture Sciences, 50(4): 12081217

16. Rasheed, Z.K. 2017. Water Movement From Buried Vertical Ceramic Pipes Through Soils. Msc. Thesis, Dept. Of Water Resources Engin., Coll. Of Engin., Univ. of Baghdad, pp.53

17. Rasheed, Z.K. 2020. Analysis the wetted area for subsurface drip irrigation in different soils texture. Iraqi Journal of Agriculture, 51(2):712-722

18. Siyal, A.A., and T.H. Skaggs. 2009. Measured and simulated soil wetting patterns under porous clay pipe sub-surface irrigation Agricultural Water Management, 96: 893-904 19. Siyal, A.A., A.G. Siyal and M.Y. Hasini. 2011. Crop production and water use efficiency under subsurface porous clay pipe irrigation. Pak. J. Agri., Agril. Engg., Vet Sci., 27(1): 39-50.

20. Van Genuchten, M.Th. 1980. A closedform equation for predicting the hydraulic conductivity of unsaturated soils. Soil Sci. Soc. Amer. J., 44(5): 892-898

21. Vogel, T., and M. Cislerova. 1988. On the reliabity of unsaturated hydraulic conductivity calculated from moisture retention curve. Transport in Porous Media, 3: 1-15

22. Willmott, C. J. 1982. Some commets on the evaluation of model performance. Bulletin of the American Meteorological Society, 63(11): 1309-1313. 